\title{
Common sea anemones Actinia equina are predominantly sessile intertidal scavengers
}

\author{
J. Davenport*, T. V. Moloney, J. Kelly \\ School of Biological, Earth \& Environmental Sciences, University College Cork, Distillery Fields, North Mall, Cork, Ireland
}

\begin{abstract}
Coelenteron contents of anemones Actinia equina collected from 2 shore heights (upper and lower) on 3 shores (exposed, semi-exposed and sheltered) in south-west Ireland were investigated in summer 2009. Diets of exposed and semi-exposed shore anemones were dominated by small mussels Mytilus edulis, mostly (>90\%) with broken/cracked shells. The diet of anemones on the sheltered shore was dominated by insects, particularly on the upper shore. On all shores, larger food items (isopods, mussels, insects) were broken or fragmented; only small gammarid amphipods, crab megalopae, midges and mosquitos were found whole. Laboratory behavioural experiments showed that $A$. equina were unselective at small prey size, but were limited by their own size, which restricted the maximum size of prey that could be ingested. Whole mussels were ingested, but egested alive after mean elapsed times of 0.75 to $1.95 \mathrm{~h}$ (depending upon anemone size). In contrast, mussels with cut adductor muscles, and incapable of shell valve closure, were fully digested, empty shells not being egested until 8.70 to $8.95 \mathrm{~h}$ after ingestion. Whole, live mealworms Tenebrio molitor were eaten by anemones, but were egested after a mean $1.30 \mathrm{~h}$ with no signs of digestion or fragmentation. Mealworms with mechanically perforated exoskeletons were held in the coelenterons of $A$. equina for a mean of $5.90 \mathrm{~h}$ and all soft tissues were digested. It was concluded that $A$. equina predominantly scavenges on macrofaunal carrion, as well as preying upon smaller food items.
\end{abstract}

KEY WORDS: Sea anemones · Actinia equina $\cdot$ Scavengers $\cdot$ Carrion

\section{INTRODUCTION}

The beadlet sea anemone Actinia equina (L.) is a common intertidal actinian anthozoan on Atlantic rocky shores of all exposure types in Western Europe; a conspecific (A. mandelae Wirz \& Delius) also occurs on the west African coast and has been studied extensively (e.g. Kruger \& Griffiths 1997, 1998). A. equina is most abundant on the lower shore, particularly on exposed coasts, but is also found on the middle and upper shore, especially in rock pools, as well as in damp crevices. Upper and lower distributional limits of mean low water springs (MLWS) and mean high water neaps (MHWN) were given by Quicke et al. (1985), indicating that the species is an intertidal specialist (though it is subtidal in the microtidal Mediterranean; Chintiroglou \& Koukouras 1992). Much of its biology was reviewed by Shick (1991).
The feeding ecology of Actinia equina is generally assumed to be similar to that of many other sea anemones that are characterized as opportunistic omnivores (Van-Praët 1985, Shick 1991) and generalists (Kruger \& Griffiths, 1998). Technically, beadlet anemones are sedentary, since they are capable of very slow movement, but in terms of feeding they are regarded as sessile sit-and-wait predators that appear to feed on whatever falls onto the tentacles and oral disc (Shick 1991). While some anemones have long tentacles and actively catch benthic prey, A. equina has short tentacles and appears to be a suspension feeder (Chintiroglou \& Koukouras 1992). Adhesive spirocysts (as well as nematocysts) on the tentacles are involved in food capture, while killing of prey apparently takes place in the coelenteron, where nematocysts are the only cnidae present on the mesenteries (Van-Praët 1985). There is a considerable literature 
devoted to digestion and absorption of food (see VanPraët 1985 for review).

The most quantitative account of the diet of Actinia equina in Europe has been provided by Chintiroglou \& Koukouras (1992), but their information was derived from subtidal Mediterranean animals, most of which $(70 \%)$ had empty coelenterons. They also implied that beadlet anemones exhibited food preferences, although earlier studies had indicated that $A$. equina simply ate items that fell onto the tentacles and oral disc (e.g.Van-Praët 1985). The study reported here was primarily designed to investigate the diet of intertidal $A$. equina living at different heights on shores of various wave exposure levels. It was hypothesised that diets would vary amongst shores and shore heights because of stochastic processes determining the availability of food items. As a result of the findings, subsequent laboratory feeding experiments were conducted to determine (1) whether anemones could select food items of different sizes, (2) whether they were predators or scavengers, and (3) whether they could distinguish between inorganic and organic material. Additional data concerning anemone appetite were also collected for comparison with the quantities of material found in the coelenterons of anemones taken from the field.

\section{MATERIALS AND METHODS}

Collection and sampling. Specimens of Actinia equina were collected from 3 shores in south-west Ireland in summer 2009 (Fig. 1) on 3 different days. Specimens for coelenteron contents analysis were collected from the high water neap (HWN) level and low water leap (LWN) level at Garrettstown (51 $38^{\prime} 61^{\prime \prime} \mathrm{N}$, $\left.8^{\circ} 35^{\prime} 1^{\prime \prime} \mathrm{W}\right)$, Bullens Bay $\left(51^{\circ} 38^{\prime} 48^{\prime \prime} \mathrm{N}, 8^{\circ} 32^{\prime} 52^{\prime \prime} \mathrm{W}\right)$ and Tralispean (51 $\left.{ }^{\circ} 29^{\prime} 51^{\prime \prime} \mathrm{N}, 9^{\circ} 13^{\prime} 45^{\prime \prime} \mathrm{W}\right)$. Between 19 and 26 anemones were collected from each site/shore height combination. Garrettstown is an exposed, mussel-dominated (cf. Lewis 1964) rocky shore (Ballantine Scale 3; Ballantine 1961). Bullens Bay is a moderately exposed shore (Ballantine Scale 4) situated in a sheltered inlet east of the Old Head of Kinsale, which shields the shore from prevailing south-west winds. Its lower shore exhibits mixed barnacle/mussel domination. Tralispean is completely sheltered from prevailing winds (Ballantine Scale 7) and the lower shore has a mixed fucoid and barnacle cover, with low densities of larger mussels. In all cases, anemones were collected on falling tides within a few minutes of the tide leaving them, to minimise time available for digestion of coelenteron contents. On the days of collection, Garrettstown and Bullens Bay both experienced moderate wave action with swell and surge; at Tralispean waves were absent.

Coelenteron contents analysis. All specimens $(\mathrm{n}=$ 123) were preserved in $70 \%$ ethanol immediately and stored individually in $5 \times 5 \mathrm{~cm}$ ziplock bags until taken to the laboratory. Anemones were dissected and examined under a stereoscopic dissecting microscope (Nikon). Dissection involved cutting the specimens in half from the oral disc to the basal disc in Petri dishes with $\sim 2 \mathrm{~mm}$ depth of $70 \%$ ethanol. Any other items in the ziplock bag were also moved to the Petri dish in case the specimen had egested prey after exposure to alcohol (Sebens 1981). First the alcohol was searched for possible food items; next the tentacles of the specimen were inspected and finally the coelenteron contents were examined for food items by scraping. This was achieved by removing all gut contents including

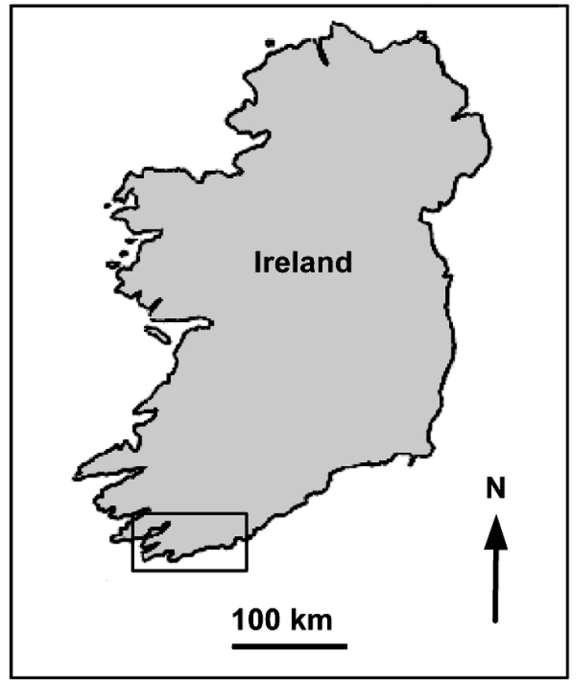

Fig. 1. Study site locations. Prevailing winds are south-west
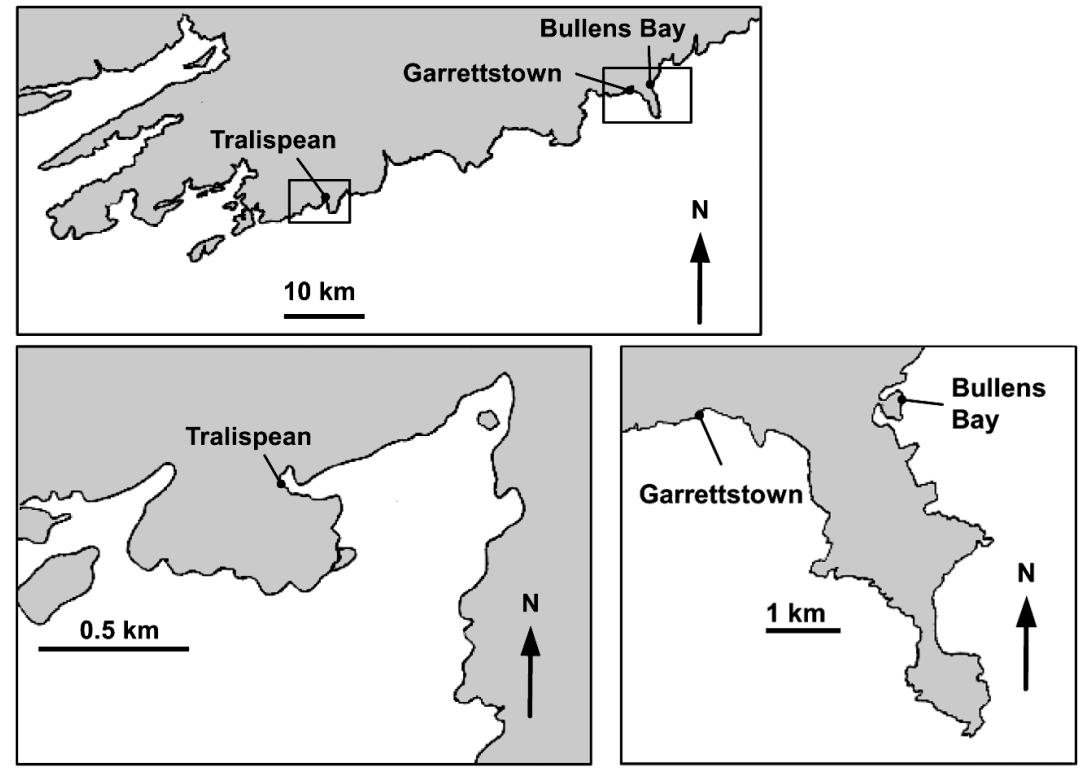
food bolus, mesenterial filaments, mesenteries, gonad and any juvenile anemones present. Food items were identified to the lowest possible taxonomic level and counted. Counting of fragmented animal material was carried out carefully to determine the minimum number of animals that a set of fragments corresponded to. It was impractical to estimate ingested biomass as much material was substantially digested.

Behavioural experiments. Anemones used in behavioural experiments were gently removed from the substratum at either Garrettstown or Bullens Bay (depending upon weather), taking care to ensure that the pedal disc was not damaged. They were held in aerated seawater (salinity $34 \mathrm{psu}$ ) in individual polystyrene containers that each contained a pebble to allow the anemone to attach itself. The containers were held in large glass aquaria and the seawater was changed weekly. They were maintained on a diet of crushed small mussels Mytilus edulis.

Prey size selection: For feeding experiments, the specimens of Actinia equina were divided into 3 size classes; small (<15 mm basal disc diameter), medium (15 to $30 \mathrm{~mm}$ basal disc diameter) and large (>30 mm basal disc diameter). Before feeding experiments, specimens were not fed for $2 \mathrm{~d}$ to standardize appetite. Selection of small prey of different sizes was investigated by feeding brine shrimp Artemia of different sizes as proxies for zooplankton to 5 anemones of each size class kept individually in plastic beakers $(800 \mathrm{ml})$ filled with aerated seawater (35 psu) at 19.7 to $20.8^{\circ} \mathrm{C}$. Each anemone size (5 replicates per size class) was given a known number of Artemia of various sizes (newly hatched, mean length $0.625 \mathrm{~mm}$; larger nauplii, mean length $1.28 \mathrm{~mm}$; subadult, mean length $2.76 \mathrm{~mm}$; adult, mean length $3.1 \mathrm{~mm}$ ). Each anemone was offered either 50 newly hatched, 40 nauplii, 30 subadult or 15 adult Artemia by $1 \mathrm{ml}$ pipette. After $2 \mathrm{~h}$ the seawater was removed from the beaker and any remaining brine shrimps were counted to allow calculation of the number eaten.

Selection of prey of various larger sizes was investigated using whole, live mussels Mytilus edulis of a range of known shell lengths. Individual anemones (5 each of size categories small, medium, large) were each held in a beaker and offered a large mussel by dropping it onto the oral disc. If not ingested within $30 \mathrm{~min}$, the mussel was removed and a slightly smaller size mussel offered. This process was repeated until the anemone ingested the offered mussel within $30 \mathrm{~min}$, at which point it was assumed that the upper prey size threshold had been reached.

Appetite: Ten Actinia equina of wet body masses from 1 to $5.4 \mathrm{~g}$ were used to evaluate appetite (in terms of satiation ration). The anemones were not fed for $1 \mathrm{wk}$ and their wet masses (when out of water and con- tracted) established. Each was then offered pieces of mussel flesh (each $0.15 \mathrm{~g}$ ) by placing the pieces on the anemone's tentacles using forceps. If the anemone extended its tentacles after ingestion (defined as the moment at which the ingested flesh was no longer visible in the mouth), another piece of mussel flesh was offered. This process was continued until the anemone showed no signs (e.g. transfer of flesh to the mouth) of ingesting a piece of flesh 15 min after it was placed on the tentacles. The individual satiation ration was calculated from the summed ingested flesh mass.

Ingestion and egestion of mussels: Mytilus edulis were also offered to Actinia equina to determine how long it would take them to process (ingest, digest, egest) mussels. Single whole, live mussels (close to, but below the upper prey size threshold already determined) were fed to 5 anemones in each of the 3 size classes. Mussels were placed on the oral disc of the anemones and were completely ingested within $30 \mathrm{~min}$. The anemones were periodically observed until they egested the mussel shells. To further elucidate processing of mussels, the experiment was repeated using mussels in which the adductor muscles had been cut, so that the shell valves remained open and the flesh exposed to the contents and structures of the coelenteron.

Survival of ingestion: Single intact mussels were ingested by each of 10 large anemones that had been starved for $48 \mathrm{~h}$. After $2 \mathrm{~h}$ they were inspected and all had egested mussels in the interim. The mussels were placed in a glass dish, covered with seawater (salinity 34 ) and inspected under a binocular microscope for signs of life (protrusion of foot, movements of shell valves).

Experiments with insect material: Larvae (mealworms) of the darkling beetle Tenebrio molitor were used as proxies for insect material ingested by Actinia equina. Ten large anemones, not fed for $48 \mathrm{~h}$, ingested whole, live mealworms of 12 to $15 \mathrm{~mm}$ length. They were observed until the mealworms were ingested. The experiment was repeated with a further 10 anemones, but in this case the mealworms were killed and holes made with a sharp scalpel in each of the body segments before they were ingested by the anemones. In both experiments, the mealworm material was inspected subsequent to egestion under a binocular microscope to determine the state of digestion.

Experiments with plastic pellets: Fasted anemone of each size class were separately fed each of 3 types of negatively buoyant 'food grade' alkathene pellets (length $2.18 \mathrm{~mm}$ ): (1) clean, (2) pellets coated with a biofilm (pellets held in sunlit unfiltered seawater for $7 \mathrm{~d}$ ), and (3) pellets coated with mussel extract (extract coat left to air dry for $24 \mathrm{~h}$ before experiments). Each anemone was offered one pellet of each type by dropping it onto the oral disc and observed for $30 \mathrm{~min}$ to determine whether the pellets were ingested. 
Table 1. Vacuity coefficient and mean number of food items in non-empty coelenterons of Actinia equina sampled in SW Ireland in June 2009

\begin{tabular}{|lcc|}
\hline Site (shore height) & $\begin{array}{c}\text { Vacuity } \\
\text { coefficient } \\
(\%)\end{array}$ & $\begin{array}{c}\text { Mean no. } \\
\text { animals per } \\
\text { coelenteron }\end{array}$ \\
\hline $\begin{array}{l}\text { Garrettstown } \\
\text { (exposed) }\end{array}$ & & \\
$\begin{array}{l}\text { High shore } \\
\text { Low shore } \\
\text { Bullens Bay } \\
\text { (semi-exposed) }\end{array}$ & 8.6 & 2.86 \\
$\quad$ High shore & 15.7 & 2.29 \\
Low shore & & \\
$\begin{array}{l}\text { Tralispean } \\
\text { (sheltered) }\end{array}$ & 9.0 & 2.40 \\
High shore & 4.0 & 5.87 \\
Low shore & & 1.67 \\
\hline
\end{tabular}

\section{RESULTS}

\section{Coelenteron contents analysis}

Vacuity coefficients and numbers of animal food items. Empty coelenterons were found in anemones sampled from all shores and shore heights (Table 1), though there was no obvious pattern in incidence. The overall vacuity coefficient across all 3 shores and 2 shore heights was $9.2 \%$. Although over $90 \%$ of coelenterons contained food items, the numbers of individual items found per coelenteron was low (Table 1), mean values ranging from 1.67 (high shore, Tralispean) to 5.87 (low shore, Bullens Bay).

Taxonomic composition of contents. All identifiable taxa found in the coelenterons are listed in Table 2. With the exception of allochthonous terrestrial plant and insect material, almost all other items were of marine benthic or benthonic origin; planktonic or nektonic items were generally not found. The barnacle cyprids and crab megalopae observed are settlement stages; they could either have been caught when in the plankton, or when moving over rock surfaces. Most of the marine material was probably of autochthonous rocky intertidal origin. However, some were definitely allochthonous; the tubiculous polychaete Sabellaria alveolata occurs in reefs of sandy tubes several hundreds of metres from the Garrettstown collection site. No material of anthropogenic origin was found. Although small pieces of rock were often present, they were almost always partially covered by coralline algal layers.

Quantities of food items. Table 3 summarizes the relative occurrence of the major groups of organisms found within the coelenterons. Molluscs (particularly Mytilus edulis) dominated the diet at the exposed shore and the lower part of the semi-exposed shore. They made up a higher proportion of the diet on the lower shore than the upper shore. In contrast, at the sheltered site (Tralispean), molluscs were unimportant and coelenteron contents were dominated by crustaceans (predominantly crab megalopae) and insects (especially on the upper shore, where $41.5 \%$ of coelenteron contents were made up of winged insects).

Table 2. Actinia equina. Taxonomic composition of items found in coelenterons on 3 shores in SW Ireland in June 2009

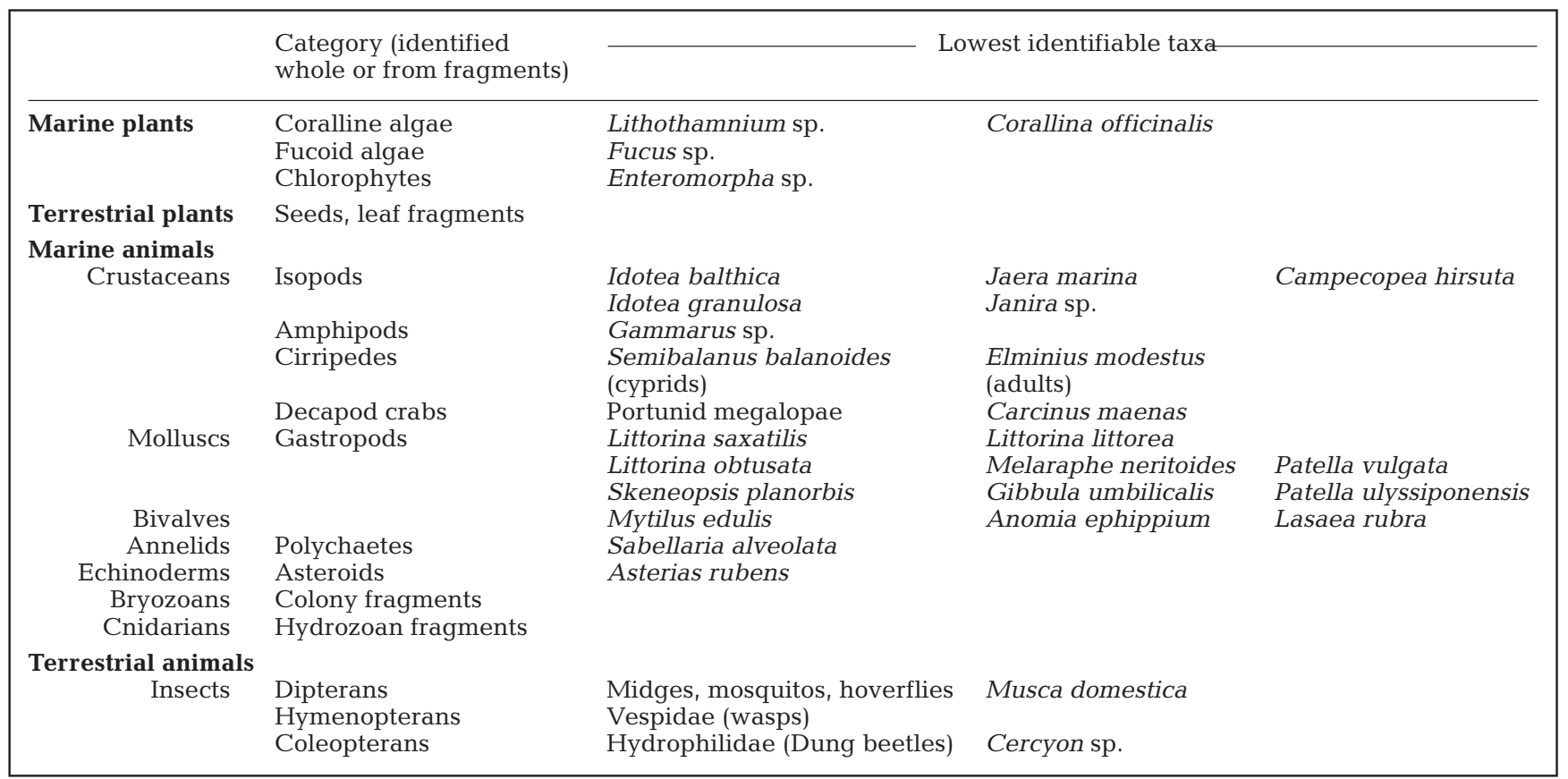


Table 3. Relative frequency (\%) of major items found in coelenterons of Actinia equina on 3 shores in SW Ireland in June 2009. Note that 'macroalgae' includes coralline algae as well as other taxa, and that 'molluscs' includes Mytilus edulis as well as other bivalves and gastropods

\begin{tabular}{|c|c|c|c|c|c|c|}
\hline \multirow[t]{2}{*}{ Taxa } & \multicolumn{2}{|c|}{$\begin{array}{c}\text { Garrettstown } \\
\text { (exposed) }\end{array}$} & \multicolumn{2}{|c|}{$\begin{array}{c}\text { Bullens Bay } \\
\text { (semi-exposed) }\end{array}$} & \multicolumn{2}{|c|}{$\begin{array}{l}\text { Tralispean } \\
\text { (sheltered) }\end{array}$} \\
\hline & High shore & Low shore & High shore & Low shore & High shore & Low shore \\
\hline Macroalgae & 16.3 & 12.5 & 7.5 & 5.0 & - & 20.9 \\
\hline Coralline algae & 11.6 & 5.5 & - & - & - & 3.0 \\
\hline Molluscs & 37.3 & 75.5 & 11.3 & 62.3 & 7.2 & 6.0 \\
\hline Mytilus edulis & 29.0 & 72.2 & 5.7 & 44.6 & 4.8 & 4.5 \\
\hline Crustaceans & 20.9 & 4.1 & 54.6 & 14.1 & 36.6 & 38.7 \\
\hline Insects & - & - & 7.5 & 7.8 & 41.5 & 17.9 \\
\hline
\end{tabular}

Condition of contents. In considering the nature of the contents, it has to be recognized that they are not comparable with stomach contents of predators such as fish, prawns or squid that have plug flow guts, because the coelenteron contains fully digested material as well as newly ingested food items. Turnover time of different food items is known to differ (Kruger \& Griffiths 1998), which will also influence coelenteron content. Algae were invariably present as fragments or, in the case of coralline algae, as crusts on rock fragments. Molluscan material varied in condition. Gastropod shells were usually whole (though the contents were digested), but the majority of bivalves (>90\%) had cracked or broken shell valves and in some cases soft tissue was still present. The exoskeletons of some crustaceans, particularly gammarid amphipods and crab megalopa, were largely intact, but many isopods of the genus Idotea were present as pieces. Many insects (except midges and mosquitos) were present as pieces (e.g. head, thorax or abdomen), rather than as whole animals. Overall, the biomass of ingested and digested material present within the coelenterons was very low by comparison with the quantities of material that the anemones are capable of ingesting (see section below).

\section{Behavioural experiments}

Prey size selection. All sizes of Artemia were ingested (Table 4). Anemones captured and ingested material $<1 \mathrm{~mm}$ size, but the proportion of newly hatched Artemia ingested was lower than that of larger brine shrimps. There was an upper limit to the size of food item ingested as anemones could not ingest mussels with shell lengths greater than about $60 \%$ of pedal disc diameter (Fig. 2).

Appetite. All 10 anemones ingested mussel flesh, none rejected it and the wet satiation ration ranged from $34.7 \%$ of wet body mass in a $1 \mathrm{~g}$ anemone to $13.1 \%$ in a $5 \mathrm{~g}$ anemone (Fig. 3). Visually, these quan- tities of food greatly exceeded the amounts of material found during inspection of the coelenterons of wildcaught anemones.

Ingestion and egestion of mussels. Intact mussels (capable of shell valve closure) and mussels with cut adductor muscles (incapable of closure) were processed in markedly different ways (Table 5). Intact mussels were egested by anemones a median of $0.93 \mathrm{~h}$ after ingestion, apparently undigested. Mussels with cut adductors were egested much later (overall median $7.73 \mathrm{~h}$ ) and their flesh had been digested, so that only the shells remained. Median elapsed times between ingestion and egestion were different to an highly significant extent (Kruskal-Wallis test: $\mathrm{p}=0.004$ ).

Survival of ingestion by mussels. Although egested intact mussels sometimes had a coating of mucous material, they resumed normal activity (foot and shell valve movement; reactions of the mantle edge to touch)

Table 4. Ingestion of Artemia by Actinia equina

\begin{tabular}{|c|c|c|c|}
\hline $\begin{array}{l}\text { Anemone } \\
\text { size }\end{array}$ & $\begin{array}{l}\text { Pedal disc mean } \\
\text { diameter }(\mathrm{mm})\end{array}$ & $\mathrm{SD}$ & $\%$ ingested \\
\hline \multicolumn{4}{|c|}{$\begin{array}{l}\text { Newly hatched Artemia (mean length } 0.62 \mathrm{~mm} \text { ), } \\
50 \text { offered to each anemone }\end{array}$} \\
\hline Large & 33.0 & 2.7 & 56.0 \\
\hline Medium & 18.8 & 2.4 & 50.8 \\
\hline Small & 12.0 & 2.9 & 66.4 \\
\hline \multicolumn{4}{|c|}{$\begin{array}{l}\text { Artemia nauplii (mean length } 1.28 \mathrm{~mm} \text { ), } \\
40 \text { offered to each anemone }\end{array}$} \\
\hline Large & 32.1 & 5.5 & 80.0 \\
\hline Medium & 23.5 & 2.7 & 84.5 \\
\hline Small & 8.7 & 4.5 & 64.0 \\
\hline \multicolumn{4}{|c|}{$\begin{array}{l}\text { Artemia subadults (mean length } 2.76 \mathrm{~mm} \text { ), } \\
30 \text { offered to each anemone }\end{array}$} \\
\hline Large & 32.3 & 2.9 & 90.7 \\
\hline Medium & 21.9 & 1.9 & 92.0 \\
\hline Small & 11.1 & 4.4 & 79.3 \\
\hline \multicolumn{4}{|c|}{$\begin{array}{l}\text { Artemia adults, (mean length } 3.10 \mathrm{~mm} \text { ), } \\
15 \text { offered to each anemone }\end{array}$} \\
\hline Large & 32.1 & 10.1 & 84.0 \\
\hline Medium & 26.2 & 4.4 & 92.0 \\
\hline Small & 13.0 & 4.4 & 77.3 \\
\hline
\end{tabular}




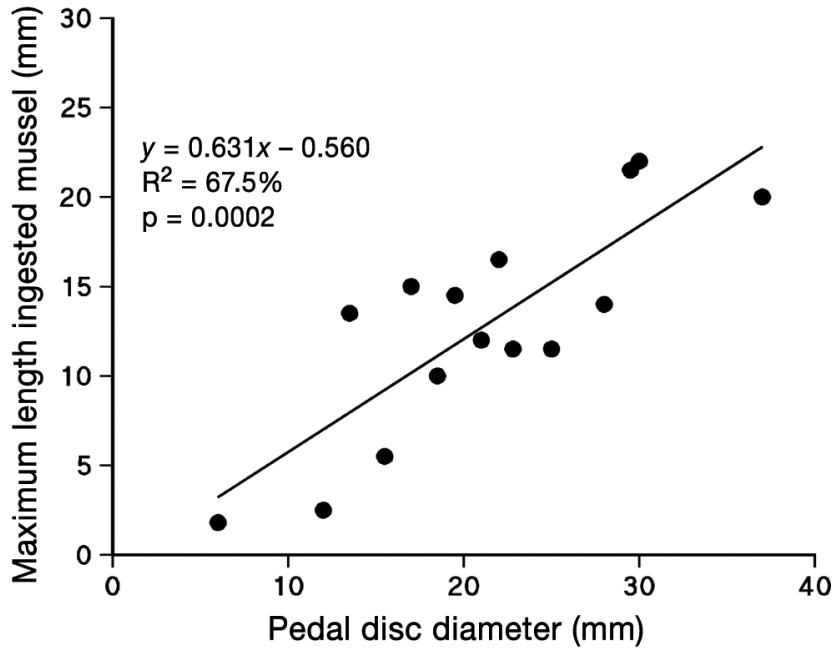

Fig. 2. Actinia equina and Mytilus edulis. Relationship between anemone size (pedal disc diameter) and maximum length of ingested mussels

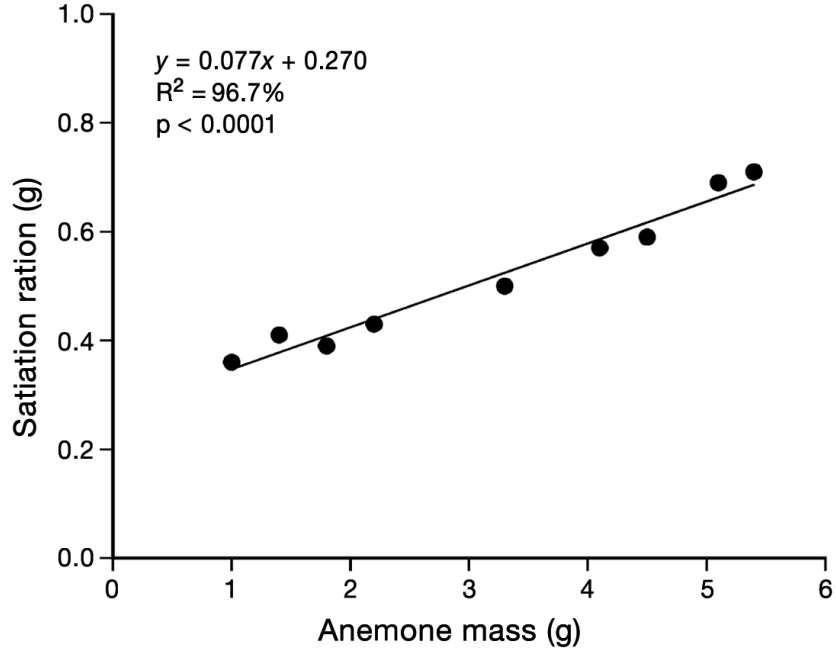

Fig. 3. Actinia equina and Mytilus edulis. Relationship between anemone wet mass and satiation ration (flesh wet mass) measured under laboratory conditions

Table 5. Actinia equina and Mytilus edulis. Time interval between ingestion and egestion of mussels by anemones: comparison of processing of intact mussels and mussels with cut adductor muscles

\begin{tabular}{|c|c|c|c|c|c|c|}
\hline Anemone size & $\begin{array}{c}\text { Mean anemone } \\
\text { pedal disc } \\
\text { diameter (mm) }\end{array}$ & $\mathrm{SD}$ & $\begin{array}{c}\text { Mean length } \\
\text { ingested mussel } \\
(\mathrm{mm})\end{array}$ & $\mathrm{SD}$ & $\begin{array}{l}\text { Median interval } \\
\text { between ingestion } \\
\text { and ejection }(\mathrm{h})\end{array}$ & $\mathrm{SD}$ \\
\hline \multicolumn{7}{|l|}{ Intact mussels } \\
\hline Large & 32.8 & 5.51 & 17.6 & 1.56 & 2.12 & 1.17 \\
\hline Medium & 26.7 & 2.50 & 13.9 & 0.48 & 1.58 & 2.10 \\
\hline Small & 10.6 & 2.06 & 5.7 & 1.44 & 0.86 & 0.35 \\
\hline \multicolumn{7}{|c|}{ Mussels with cut adductors } \\
\hline Large & 32.0 & 3.26 & 17.60 & 0.89 & 7.73 & 2.21 \\
\hline Medium & 23.7 & 4.16 & 12.83 & 0.29 & 6.93 & 2.18 \\
\hline Small & 12.7 & 3.23 & 7.00 & 3.37 & 3.73 & 1.60 \\
\hline
\end{tabular}

Table 6. Actinia equina. Ingestion of alkathene pellets (length $2.18 \mathrm{~mm})$

\begin{tabular}{|lccc|}
\hline $\begin{array}{l}\text { Anemone } \\
\text { size }\end{array}$ & \multicolumn{4}{c|}{$\begin{array}{c}\text { No. of pellets ingested (out of 5) } \\
\text { Clean } \\
\text { pellets }\end{array}$} & $\begin{array}{c}\text { Pellets with } \\
\text { biofilms }\end{array}$ & $\begin{array}{c}\text { Pellets } \\
\text { coated with } \\
\text { mussel extract }\end{array}$ \\
\hline $\begin{array}{l}\text { Small } \\
\text { Medium }\end{array}$ & 2 & 1 & 2 \\
Large & 0 & 1 & 4 \\
Total (out of 15) & 3 & 2 & 4 \\
\hline
\end{tabular}

on return to seawater. Mussels with cut adductors were egested much later as shells; their flesh had been digested.

Experiments with insect material. Of the 10 anemones fed live intact mealworms, 5 did not ingest them, but released them from the tentacles (dead as a result of drowning) within 15 to $30 \mathrm{~min}$. All 5 anemones that ingested live intact mealworms egested them after a median $1.3 \mathrm{~h}$. The egested mealworms were dead, but intact, with no signs of digestion or fragmentation. Some were coated with mucous material.

Of the 10 anemones fed dead, perforated mealworms, 4 discarded the mealworms, which were not ingested. The remaining 6 ingested their perforated mealworms and held them in the coelenterons for a median $5.9 \mathrm{~h}$ before egestion. The elapsed times between ingestion and egestion differed between the 2 groups to a highly significant extent (Kruskal-Wallis test: $p=0.006$ ). The egested mealworms each exhibited a whole, perforated exoskeleton (i.e. not fragmented), but a completely watery, liquid interior, indicating full digestion of the internal organs.

Experiments with plastic pellets. Anemones ingested few clean pellets or pellets only coated in a biofilm (20 and $13 \%$, respectively); the presence of a biofilm did not make the pellets more attractive (Table 6). However, $67 \%$ of the pellets coated with mussel extract were ingested, indicating that such extract enhanced 
attractiveness of the plastic material. All ingested pellets were egested in less than $1 \mathrm{~h}$.

\section{DISCUSSION}

From the results presented it is evident that the coelenteron contents of Actinia equina are strongly dependent on shore exposure and shore height. This would be expected from an omnivorous sessile suspension feeder that simply ingests available material delivered stochastically to it by tides, currents and wave action. Chintiroglou \& Koukouras (1992) divided the diet of Mediterranean subtidal sea anemones into categories of 'preferential' (making up $>50 \%$ of total food items), 'secondary' (10 to $50 \%$ ) and 'accidental' $(<10 \%)$. These terms originate in fish diet composition studies (e.g. Deniel, 1975), but we believe they are misleading in the context of a species that cannot actively seek out preferred prey. Chintiroglou \& Koukouras (1992) found $70 \%$ of subtidal A. equina in Greek waters to have no material in their coelenterons (in summer). The diet of the remaining 30\% was dominated (45\%) by 'organic detritus', with insects, crustaceans and molluscs being the most important identifiable items. Clearly the intertidal $A$. equina reported on here received a more plentiful summer diet, as the mean vacuity coefficient was only 9.2\%. Low-shore coelenteron contents were dominated by mussels (72.2 and $44.6 \%$ at exposed and semi-exposed sites, respectively; Table 3), while high-shore anemones contained proportionately fewer mussels (29.0 and $5.0 \%$ at exposed and semi-exposed sites, respectively). Marine mussels (Mytilidae) on rocky shores have long been known to compete for space and food and to exhibit self-thinning (e.g. Hughes \& Griffiths 1988, Guiñez 2005), a process by which mussels are ejected from 2- or 3-dimensional beds. It is also known that storms and heavy wave action make ejection of mussels much more likely (e.g. Harger \& Ladenberger 1971). In consequence, on high-energy shores with extensive low-shore mussel beds, small mussels are continually being ejected and presumably battered against rocks by wave action. Rocky shore mussels are also extensively preyed upon by shore crabs Carcinus maenas, and mussels damaged by crabs are likely to add to the numbers available to anemones. Since mussels have a high body density, because of their calcareous shell valves, it is likely that fewer will be thrown up by wave action to high-shore $A$. equina, hence the difference in importance to anemone diet. The data for the sheltered shore at Tralispean reinforce this hypothesis: with negligible wave action and no low-shore mussel mats, mussel occurrence was low and similar on low and high shores (4.5 and $4.8 \%$, respectively).
The importance of mussels Mytilus edulis to the diet of Actinia equina on Irish coasts mirrors the data presented by Kruger \& Griffiths (1998) for A. mandelae at the south-western Cape, South Africa. They found an overwhelming dominance of bivalve molluscs (of several species, including 2 mussel species), but also reported amphipods, isopods and insects.

The incidence of insects in the diet of Actinia equina in south-west Ireland is also explicable in terms of exposure. Garretstown, the most exposed site studied, is subject to prevailing onshore south-west winds, presumably carrying few insects; hence, no insects were recorded from coelenterons either on the high shore or low shore at this site. The Bullens Bay semi-exposed collection site was about 200 to $250 \mathrm{~m}$ away from arable farmland and the prevailing south-west winds are offshore. Insect incidence in coelenterons was $7.5 \%$ on the high shore, $7.8 \%$ on the low shore. The highly sheltered shore at Tralispean was adjacent to pasture land, hedges, shrubs and trees, all rich in insect life. Prevailing winds were offshore. At Tralispean, insect incidence in coelenterons was $41.5 \%$ on the high shore nearest to the terrestrial habitat and lower on the low shore $(17.9 \%)$. Insects that are carried onto seawater can rarely escape because of surface tension and soon drown. Presumably tidal rise and fall will carry them within reach of anemones' tentacles.

It has generally been accepted that Actinia equina preys upon other animals; Shick (1991) emphasised that anemones with short, thick tentacles prey upon macrofauna. Our field data, and laboratory experiments with Artemia as prey items, indicate that $A$. equina is certainly capable of catching, killing and digesting small planktonic and benthonic crustaceans such as gammarid amphipods, barnacle cyprids and crab megalopa. Whether it is a predator of larger animals (e.g. large isopods of the genus Idotea, which occurred in pieces within the coelenteron) is less clear, and it we consider it unlikely that $A$. equina is a predator of mussels and insects. Mussels of all sizes almost always had cracked or broken shells and there seems no obvious means by which $A$. equina could inflict such damage; shell valve breakage before ingestion seems far more likely. Although small insects were often found whole within the coelenteron, large insects were not. In any case, it seems most likely that insects were drowned and were carrion before ingestion. Insects are fragile and even gentle wave action is likely to break them up in the intertidal habitat.

The coelenteron of anemones is compromised in function because it also has a role in respiration, with seawater flowing to and fro between the coelenteron and the exterior (though not during digestion) (Shick 1991). In consequence, the available evidence indicates that digestion is extremely local to the surfaces of 
the mesenteries, where enzymes are secreted and macromolecules absorbed (Van-Praët 1985). The bulk fluid of the coelenteron does not feature the low $\mathrm{pH}$ and high enzyme concentrations of a typical carnivore such as a fish (Kapoor et al. 1975). From the field evidence presented here, it seemed likely that much of the anemones' diet in south-west Ireland consisted of dead, dying or damaged animals in which the anemones' mesenteries had direct access to soft tissues. This indicated that Actinia equima is predominantly a scavenger on macrofauna, an unusual attribute in a sessile animal.

The finding that Actinia equina ingested intact whole mussels, but subsequently egested them alive, them is novel and unexpected, principally because it contradicts a single study conducted more than $230 \mathrm{yr}$ ago (Dicquemare 1773), but referred to in relatively recent reviews (e.g. Shick 1991). In Dicquemare's study, live mussels of about $13.5 \mathrm{~mm}$ ('6 lines') shell length with closed shells were fed to $A$. equina of unknown size and '40, 50 and 60 hours after, the shells were thrown up at the mouth empty and perfectly cleared'. No more detail was given and it is not clear from the text (either in English translation or the original French) whether the anemones tested were in the field (in which case it is not obvious how the observer could be sure that the egested shells corresponded to the ingested mussels) or, if in the laboratory, whether or not aquarium experiments were conducted with freshly caught $A$. equina, or anemones that had been starved for long periods ( up to 12 mo in some of Dicquemare's experiments). The implication from Dicquemare's study (identified by Shick 1991) was that anemones held mussels within the coelenteron until the mussels were forced (by anoxia?) to open their shell valves and were subsequently digested. Clearly this did not happen in our study.

Because mussels with cut adductor muscles were fully digested (as was mussel flesh offered in the appetite trials), the experimental data reported here indicate that Actinia equina does not prey upon intact mussels, but scavenges on dead or damaged animals. A scavenging role was confirmed by the experiments with beetle larvae (mealworms). Again, the anemones could ingest, but not digest, intact Tenebrio molitor, yet could digest mealworm soft tissues completely when these were made available by perforation of the integument.

Since Actinia equina did not digest intact mussels or insects, why did they ingest them in the first place? It has been well known since the pioneering work of Pantin \& Pantin (1943) that sea anemones' feeding responses are triggered by chemotactile stimuli (see van Praët 1985, and Shick 1991 for extensive reviews), and the experiments reported here demonstrated that plastic pellets coated with mussel extract were ingested (though soon egested again). It is probable that $A$. equina ingests all material that provides a positive combined tactile and chemical signal. This will include pieces of macroalgae, fragments of rock with coralline algal films, whole animals and fragmented animals. Presumably all will be subject to digestive processes amongst the mesenteries, but material that does not provide feedback in terms of assimilated molecules will soon be egested.

The beadlet anemone is an intertidal specialist that reaches its highest densities on wave-cut platforms on the lower portion of Irish shores. The intertidal habit is subject to waves and surge, the water being laden with sand, stones and debris, as well as containing planktonic, nektonic and benthonic animals that can be dashed against the rocks. Offshore winds bring insects, seeds and terrestrial plant debris. Benthic animals and plants are dislodged, abraded and triturated, creating a dilute 'soup' that contains food resources ranging from macromolecules to whole animals (live and damaged). Actinia sp. were known to take up dissolved organic material (e.g. Pütter 1911, Chia 1972), to assimilate energy from bacteria and microalgae (van Praët 1985), and to predate on a range of organisms (e.g. Chintiroglou \& Koukouras 1992, Kruger \& Griffiths 1998). Our study demonstrates that its diet is heavily influenced by shore height and wave exposure, but also that $A$. equina scavenges (rather than preys) on the larger food items that it ingests.

Acknowledgements. The authors are grateful for the help of Luke Harman and Allen Whitaker in providing field support for this study.

\section{LITERATURE CITED}

Ballantine WJ (1961) A biologically defined exposure scale for the comparative description of rocky shores. Field Stud $3: 1-19$

Chia FS (1972) Note on the assimilation of glucose and glycine from seawater by the embryos of a sea anemone, Actinia equina. Can J Zool 50:1333-1334

Chintiroglou Ch, Koukouras A (1992) The feeding habits of three Mediterranean sea anemone species, Anemonia viridis (Forskal), Actinia equina (Linnaeus) and Cereus peduncalatus (Pennant). Helgol Meeresunters 46:53-68

Deniel C (1975) Régimes alimentaires d'Arnoglossus thori Kyle et d'Arnoglossus imperialis Rafinesque (Téléostéens - Bothidae) en la baie de Douarnenez. Revue Trav Inst Pêche Marit 39:105-116

Dicquemare A (1773) An essay, towards elucidating the history of the sea-anemonies. Communicated by Matthew Maty. Translated from the French. Phil Trans 63:361-403 (in French with English translation)

Guiñez R (2005) A review on self-thinning in mussels. Rev Biol Mar Oceanogr 40:1-6

Harger JR, Ladenberger DE (1971) The effect of storms as a density-dependent mortality factor on population of sea mussels. Veliger 14:195-201 
Hughes RN, Griffiths CL (1988) Self-thinning in barnacles and mussels: the geometry of packing. Am Nat 132: 484-491

Kapoor BB, Smit H, Verighina IA (1975) The alimentary canal and digestion in teleosts. Adv Mar Biol 13:109-239

Kruger L, Griffiths C (1997) Digestion rates of prey eaten by intertidal sea anemones from the south-western Cape, South Africa. S Afr J Zool 32:101-106

Kruger L, Griffiths C (1998) Sea anemones as secondary consumers on rocky shores in the south-western Cape, South Africa. J Nat Hist 32:629-644

Lewis JR (1964) The ecology of rocky shores. English Universities Press, London

Pantin CFA, Pantin AMP (1943) The stimulus to feeding in

Submitted: April 27, 2010; Accepted: October 4, 2010
Anemonia sulcata. J Exp Biol 20:6-13

Pütter A (1911) Der Stoffwechsel der Actinien. Z Allg Physiol 12:297-322

Quicke DLJ, Donoghue AM, Keeling TF, Brace RC (1985) Littoral distributions and evidence for the differential postsettlement selection of the morphs of Actinia equina. J Mar Biol Assoc UK 65:1-20

Sebens KP (1981) The allometry of feeding, energetics and body size in three sea anemone species. Biol Bull 161: $152-171$

Shick JM (1991) A functional biology of sea anemones. Chapman \& Hall, London

> Van-Praët M (1985) Nutrition of sea anemones. Adv Mar Biol 22:65-99

Proofs received from author(s): February 3, 2011 